\title{
The influence of enzyme preparations on the nutritional value of cereals for poultry. A review
}

\author{
H. Jeroch', S. Dänicke ${ }^{1}$ and J. Brufau ${ }^{2}$ \\ ${ }^{\prime}$ Institute of Animal Nutrition, Agricultural Faculty of Martin-Luther-University \\ Halle-Wittenberg, \\ Emil Abderhalden-Str. 25b, 06108 Halle/Saale, FR Germany \\ ${ }^{2}$ Departamento de Nutrició Animal, \\ Centre de Mas Bové, Institut de Recerca y Tecnologia Agroalimentàries \\ Apartat 415, 33280 Reus, Spain
}

(Received 10 February 1995; accepted 6 November 1995)

\section{ABSTRACT}

Supplementation of cereal based diets for poultry with enzyme preparations may notably improve the performance, and reduce the viscosity of digesta and excreta. However, the overall effect depends on the content of anti-nutritive non-starch polysaccharides (NSP) in diet and the age of birds. The paper presents the content of anti-nutritive NSP in barley, wheat, triticale and rye, and discusses their effect on digestion processes in birds of different ages and benefits due to exogenous enzymes supplementation.

KEY WORDS: cereals, poultry, feed enzymes, nutritional value

\section{INTRODUCTION}

Application of enzymes to poultry feed includes providing the animal with exogenous enzymes. The aims of such measures are (modified according to Jeroch and Müller, 1992; Brufau et al., 1993a; Simon et al., 1993):

1. Degradation of antinutritive substances and a simultaneous increase in the availability of other nutrients (e.g. the partial degradation of B-glucan by B-glucanase is connected with improved digestibility of nutrients and an increase in metabolizability of energy).

2. Utilization of feed compounds which are not degradable by the endogenous animal enzymes.

3. Possible support of endogenous enzymes in degrading nutrients. 
4. Diminishing environmentally relevant excretions, especially excretion of $\mathrm{N}$ and $\mathrm{P}$.

5. Increase of the quality of meat products and yield in meat processing.

6. Improvement of birds welfare.

Some of these aims are the subject of the following discussion with consideration of the carbohydrases only.

\section{Digestion capacity, qualitative and quantitative aspects}

Effective application of exogenous enzymes to feed requires, in accordance with the mentioned aims, knowledge both about the compounds to be degraded in feedstuffs and the ability of the animal to degrade them. The activity of endogenous enzymes for degrading the main nutrients (protein, fat and carbohydrates) seems to be sufficient, and in most cases their degradation ability even exceed the amount of nutrients ingested (Simon et al., 1993; Wenk, 1993). However, in the case of fat digestion, poultry seems to lack the full ability to digest this nutrient in the first days of life as was indicated by Escribano et al. (1988) and Krogdahl and Sell (1989).

In case of carbohydrates, the need to distinguish between different classes of carbohydrates and their digestibility should be pointed out. Different enzymes are involved in degradation of carbohydrates. Endogenous enzymes, microbial enzymes and enzymes of plant origin play different roles in digesting carbohydrates. Only sucrose and starch are digested by endogenous enzymes, while microbial enzymes in the hindgut play a part in degrading carbohydrates not digested in the foregut. This microbial digestion provides mainly volatile fatty acids which can be used as an energy source by animal. These processes are connected with energy losses for the host. Enzymes of plant origin may support the digestion of starch or take part in a hydrolysis of water-soluble non-starch polysaccharides (NSP).

Physiological evaluation of cell wall components in cereal grains and protein feedstuffs of plant origin

Three main aspects are important in impairing the digestibility of nutrients and the metabolizability of energy. First, the components themselves may be undigestible. This aspect differs in its importance for the animal depending on the concentration of these components in the diet. Secondly, due to their chemical composition and physical structure some cell wall components include other digestible nutrients. This is the so-called "cage effect" and concerns all unsoluble cell wall components. It should be noted that many feed processing techniques result in disruption of the endosperm cell walls, and consequently, 


\begin{tabular}{|c|c|c|c|c|}
\hline \multicolumn{2}{|l|}{ Compound(s) } & Occurence & \multirow[b]{2}{*}{$\begin{array}{l}\text { Effect } \\
\text { Increase of digesta } \\
\text { viscosity, disturbances } \\
\text { in digestion and } \\
\text { absorption, slower } \\
\text { digesta passage, } \\
\text { decrease in } \\
\text { performance, moisty } \\
\text { and sticky droppings }\end{array}$} & Concerned animals \\
\hline 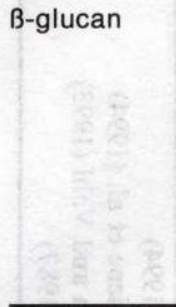 & $\frac{1}{2}$ & Barley, oats, rye & & $\begin{array}{l}\text { Chicks and other young } \\
\text { birds, especially in the } \\
\text { first weeks of life }\end{array}$ \\
\hline Pentosans & & Rye, triticale, wheat & & Poultry, Piglets \\
\hline \multicolumn{2}{|c|}{$\begin{array}{l}\text { Oligosaccharides } \\
\text { (raffinose, } \\
\text { stachyose, } \\
\text { verbascose, } \\
\text { ajugose) }\end{array}$} & $\begin{array}{l}\text { Legume seeds, } \\
\text { extracted rape } \\
\text { and soyabean meals }\end{array}$ & $\begin{array}{l}\text { Enhanced gas } \\
\text { formation }\left(\mathrm{CO}_{2}, \mathrm{H}_{2} \text {, }\right. \\
\left.\mathrm{CH}_{4}\right) \text { in the hindgut; } \\
\text { diarrhoea, flatulence }\end{array}$ & Monogastric animals \\
\hline
\end{tabular}

Figure 1. Antinutritive effects of carbohydrates

diminish the "cage effect" by improving the conditions for endogenous enzyme activity.

Regarding the practical use of exogenous enzymes, the third aspect has greater importance. The presence of soluble B-glucans, pentosans and pectins leads to an increase in viscosity of the digesta, thus impairing digestion processes in general. The special effects of these antinutritive substances is shown in Figure 1. A consequence of these depressed digestion processes is decreased nutrients digestibility. There seems to be a negative relationship between the dietary fibre content (containing all cell wall components) and the digestibility coefficients of crude nutrients, which reflects all three described effects. Whereas the effect of the undigestible cell wall components is a quantitative one (the energy of the diet is diluted) the physiological and nutritional importance of the other two mentioned effects is a subject of discussion. Pettersson and Åman (1988) attributed the poor digestibility of barley-based diets rather to the "cage effect" than the viscosity of the soluble NSP. In contrast to that, investigations carried out on hull-less barley and oats, which had lower fibre content than the hulled varieties, brought the problems of viscosity of the soluble cell wall components into focus. Despite the higher gross energy of the hull-less cereals, poorer metabolizability of energy and decreased performance and digestibility of nutrients were observed. The increase in viscosity of digesta is accepted as the most pronounced effect diminishing the feed value of the diets rich in soluble NSP (Bedford, 1992). 


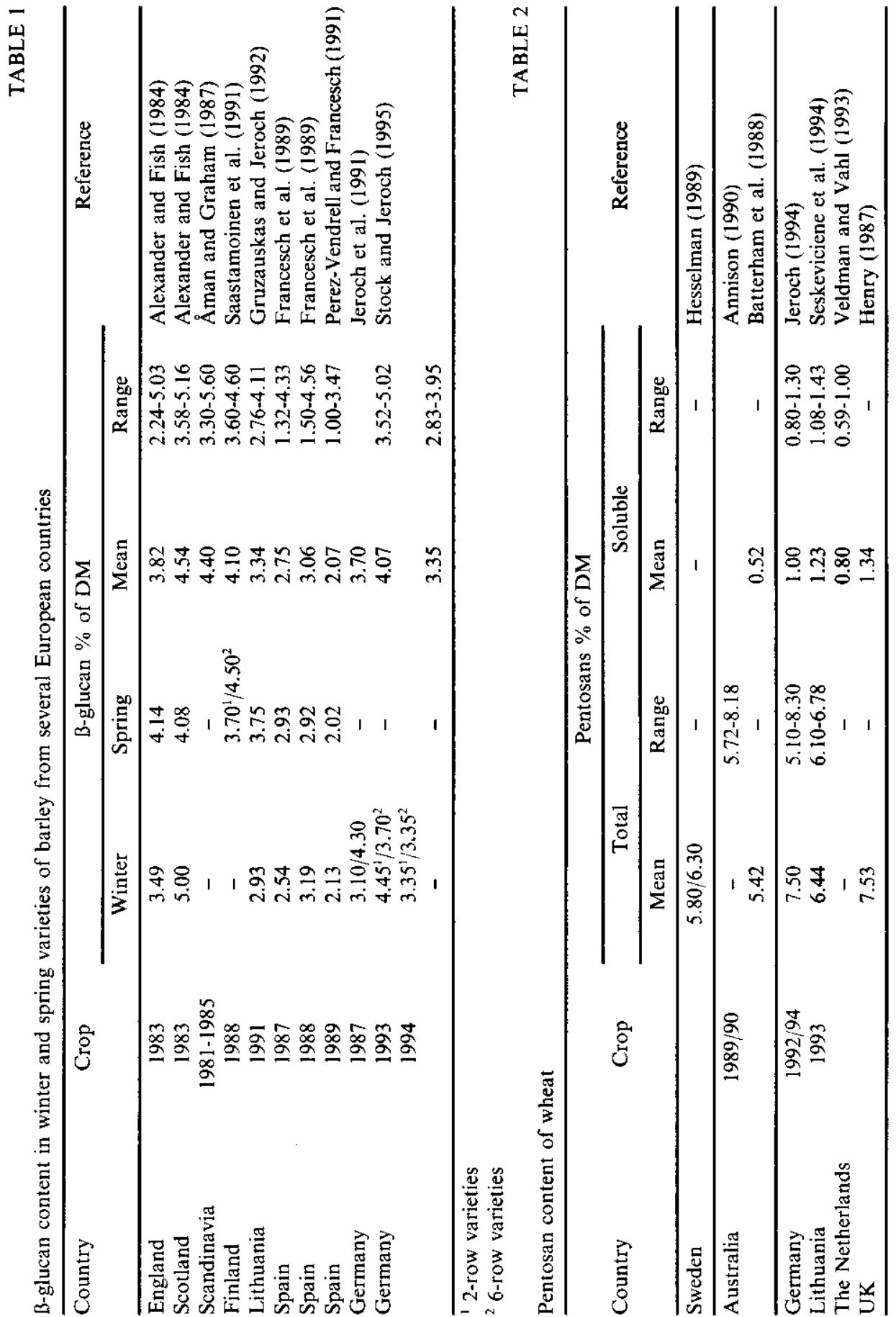




\section{Content of antinutritive NSP in wheat and barley}

Among the cereal grains, barley and wheat are important energy sources for poultry. However, these feedstuffs contain such amounts of antinutritive NSP which made it necessary to limit their use in poultry diets when no carbohydrase is supplemented. The extent of such limitation depends on the poultry species, age of birds and the content of soluble and total NSP. The total B-glucan (mixed linked $(1 \rightarrow 3)(1 \rightarrow 4)-\beta-D$ glucans) content in barleys from different areas are listed in Table 1. Many factors may influence the B-glucan content in barleys as is indicated by the wide range of its concentrations. Francesch et al. (1992) succeeded in proving the influence of environment (location and year) and the variety of barley grown in Spain on its B-glucan content, viscosity and, consequently, on the apparent metabolizable energy (AME) content in the order up to $583 \mathrm{kcal} / \mathrm{kg}$. Other factors, which may have influence on the B-glucan content are harvest time and the extent of fertilization. There seems to be a correlation between total and soluble B-glucans on one hand and between soluble B-glucans and viscosity of digesta on the other hand, as indicated by the results from Rotter et al. (1990). These correlations are not close, because there are methodological difficulties in measuring the solubility of NSP, and the conditions during solubility determination may differ from that in the alimentary tract of the animal. The values for the total and soluble pentosan (arabinoxylans) content in wheat are shown in Table 2 . It becomes clear that wheat, too, contains marked amounts of pentosans which may impair performance of the chicks.

Results of experiments with enzyme supplemented diets

\section{Broilers}

Although the conventional fattening time for broilers comprises 5 to 7 weeks, the test period frequently lasts only 14 to 21 days, beginning immediately or a few days after hatching. The rises in performance achieved in these short-term trials are often unusually high, however, they are not representative for the whole fattening period. The assessment of the enzyme effect usually decrease with increasing age, which can be explained by stabilization and adjustment of the microflora in the digestive tract to the feed. For this reason, practical recommendations should be derived only from experiments that included the whole fattening period with observance of standardized conditions. A recent evaluation of experiments made by well-known research teams in European countries and Canada furnished the results of Table 3 . The enzyme effects were 
TABLE 3

Effect of enzyme supplementation on performance of chicks fed barley, rye, triticale or wheat based diets

\begin{tabular}{|c|c|c|c|}
\hline \multirow[t]{2}{*}{ Reference } & \multirow[t]{2}{*}{ Cereals, in $\%$ of diet } & \multicolumn{2}{|c|}{$\begin{array}{l}\text { Performance, in \% } \\
\text { of control }\end{array}$} \\
\hline & & $\begin{array}{l}\text { Final body } \\
\text { weight }\end{array}$ & $\begin{array}{l}\text { Feed } \\
\text { conversion } \\
\text { ratio }\end{array}$ \\
\hline Brufau et al. (1991) & $35 / 45^{*}$ barley, $22 / 16^{*}$ maize & 102.5 & 98 \\
\hline Elwinger and Teglöff (1991) & 50 barley, 11 wheat, 10 oats & 101.5 & 99 \\
\hline Jeroch et al. (1991) & & 104 & 96.5 \\
\hline Jeroch et al. (1995) & 68 barley & 101.5 & 97.5 \\
\hline Rotter (1990) & 68.3 barley & 104 & 96 \\
\hline Salih et al. (1991) & $59.6 / 65.8$ barley & 110.5 & 92.5 \\
\hline Francesch et al. (1994) & $60 / 70$ naked barley & 100 & 97 \\
\hline Vukic Vranjes and Wenk (1993) & $40 / 45$ barley, 40 barley & 104 & 95 \\
\hline Vukic Vranjes and Wenk (1995) & 40 barley, 11.7 maize & 106 & 94 \\
\hline Brufau et al. (1993b) & & $102-103^{\prime)}$ & $100-99^{11}$ \\
\hline Gippert et al. (1994) & 40 barley, 11.7 maize, 30 barley & 103 & 96 \\
\hline Broz and Canterranne (1990) & $\begin{array}{l}20 \text { rye, } 40 \text { wheat } \\
40 \text { rye, } 25.4 \text { wheat }\end{array}$ & $\begin{array}{l}106.5 \\
112.5\end{array}$ & $\begin{array}{l}94 \\
93.5 \\
94-93.5^{1)}\end{array}$ \\
\hline Jackisch and Jeroch (1990) & 31 rye, 31 maize & $105.5-114^{1)}$ & $99-94^{\prime \prime}$ \\
\hline Jackisch and Jeroch (1992) & 15.5 rye, 46.5 maize & $104-108$ & 94.5 \\
\hline \multirow[t]{2}{*}{ Pettersson and Åman (1988) } & 57 rye & 134 & 92 \\
\hline & 30 rye, 28 maize & 110 & $98-94^{1)}$ \\
\hline Richter et al. (1990) & $20 / 30$ rye, $38 / 35$ maize & $101-109^{11}$ & \\
\hline Broz (1991) & 50 triticale & $100.5-102.5^{1)}$ & $99.5-98.5^{1)}$ \\
\hline Petterson and Åman (1988) & 57 triticale, 4 maize & 103 & 97.5 \\
\hline \multirow[t]{2}{*}{ Richter et al. (1990) } & $40 / 60$ triticale & $100.5-102.5^{1)}$ & $99-98.5^{11}$ \\
\hline & $19 / 7$ maize & $102.5-108.5^{1)}$ & $98.5-93.5^{1)}$ \\
\hline \multirow[t]{2}{*}{ Scholtyssek and Knorr (1987) } & 50 triticale & 105.5 & \\
\hline & 30 triticale, 20 maize & & 97.5 \\
\hline Carré et al. (1992) & $49.7 / 56$ wheat & $102-107.5^{11}$ & $97.5-93.5^{1)}$ \\
\hline Edney et al. (1989) & $59.6-66.6$ wheat & 100 & 100 \\
\hline Jeroch et al. (1993) & $61-64$ wheat & $101-103^{1)}$ & $98-96^{\prime \prime}$ \\
\hline McNab et al. (1993) & 66 wheat & 100.5 & 98 \\
\hline Schurz et al. $(1995 \mathrm{a})^{37}$ & $60.4 / 64.4$ wheat & $(97)-104$ & $(101)-95$ \\
\hline Pettersson and Åman (1988) & 57 wheal, 4 maize & 103 & 99.5 \\
\hline Schutte et al. (1993) & 50 wheat & 102 & 96.5 \\
\hline Francesch et al. (1994) & $40 / 45$ wheat & 100 & 97.5 \\
\hline \multirow[t]{2}{*}{ Veldman and Vahl (1993) } & 40 wheat & $100-102^{2 y}$ & $99.97^{2)}$ \\
\hline & 15 wheat, $30 / 45$ wheat & $100 / 101 / 102$ & $99 / 99 / 98$ \\
\hline Vukic Vranjes et al. (1994) & 44 wheat, 22 maize & 101 & 98 \\
\hline
\end{tabular}

1) in dependence on enzyme dosage

${ }^{2)}$ in dependence on wheat variety

3) four experiments with different enzyme dosage, without or with antibiotic supplementation

* Starter/Finisher 
mainly rather low, yet, their order was economically relevant. Above that, when rating enzyme preparations, sanitary, environmental and quality effects must be taken into account which will be elucidated below. Compared with the comprehensive trials on broiler chicks, few experiments have been made on poults and young water fowl.

\section{Laying hens}

Results from the literature on response to barley-containing layer diets are presented in Table 4. One may conclude from this survey that enzyme supplementation to barley-enriched layer diets does not influence the performance of hens. This fact may be attributed to the discussed relationship between the age of the birds and their susceptibility to the gel-forming B-glucans of barley. In recent experiments Brufau et al. (1994) found a significant increase in egg weight for hens fed the enzyme-supplemented barley-containing diets (Table 4). This effect was pronounced only in the early laying period until 34 weeks of age which was attributed to a possible improvement in digestibility of nutrients for young hens. Authors noted also a significant decrease in the water to feed ratio when enzymes were added to the barley diets, what was connected with lower viscosity of the digesta.

Decreased water consumption was also observed when barley-enriched diets supplemented with carbohydrases were fed to broilers (Francesch, 1991; Jeroch et al., 1995a). Bedford (1992) also demonstrated a decrease in digesta viscosity of laying hens fed enzyme supplemented wheat- or rye-based diets. The extent in decrease of digesta viscosity was more pronounced for the rye-fed hens than for the wheat-fed hens which was caused by the higher pentosan content of rye. High barley content in laying hen diets may contribute to the incidence of dirty eggs and sticky droppings (Herstad, 1987). After supplementation of such diets with B-glucanases this danger may be avoided.

\section{Turkeys}

In agreement with the results observed on broilers, an improvement in the performance of turkeys was found in some experiments with enzyme-supplemented barley or wheat diets (Table 5).

\section{Water fowl}

An increase in performance was also observed for geese and ducks when barley-based diets were supplemented with enzyme preparations (Table 6). 


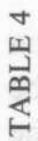

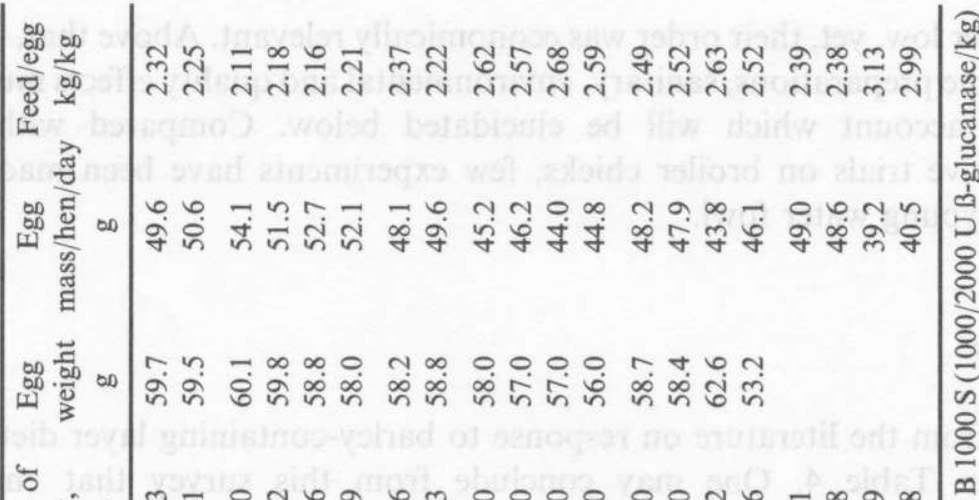

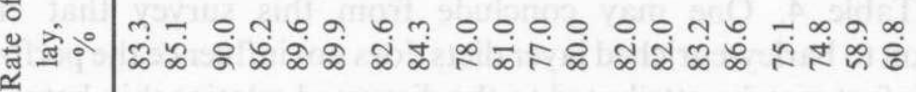

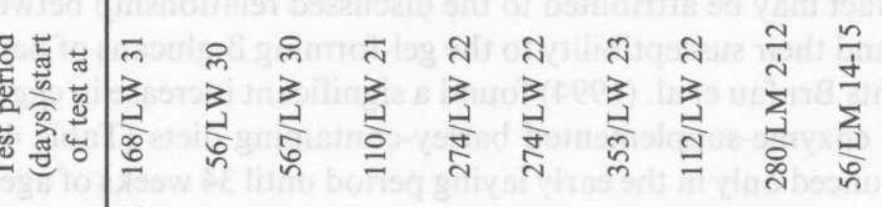

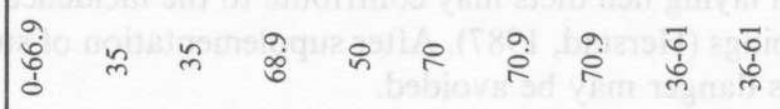




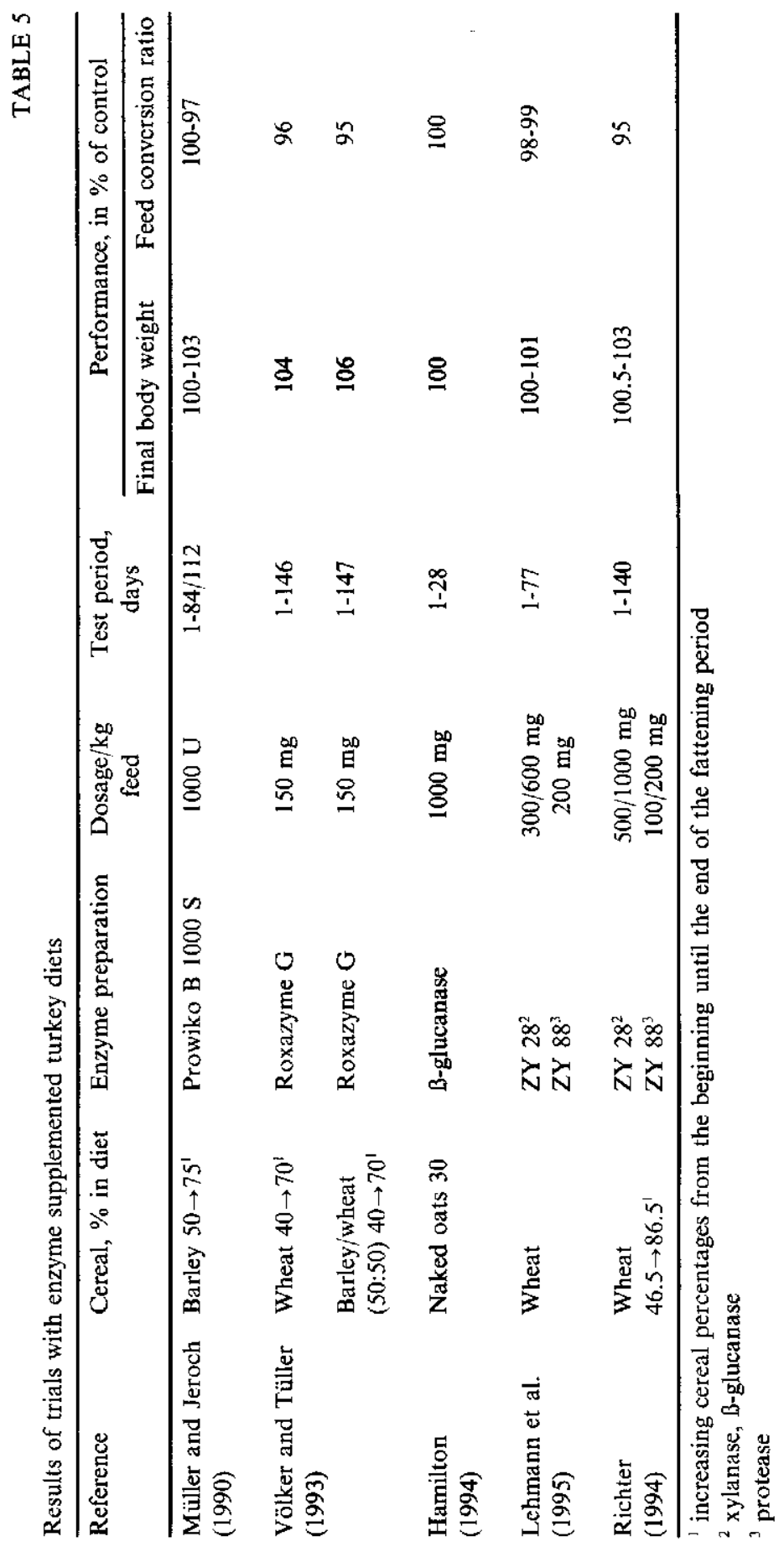


峞

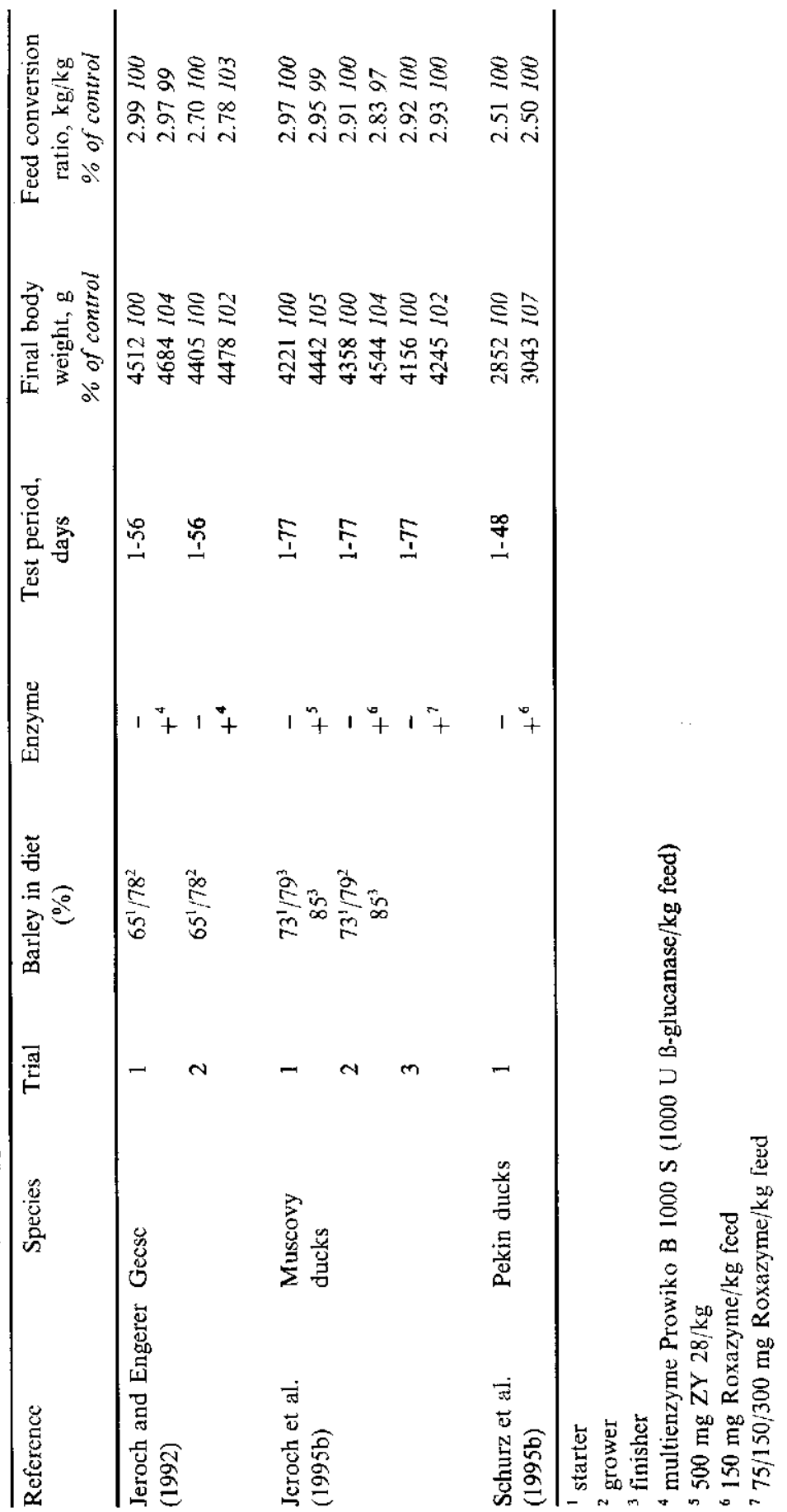




\section{Mode of action of supplemented carbohydrases}

\section{Metabolizability of energy}

The latest experiments on broilers, mainly with barley and wheat rations (high-pentosan wheat varieties) in form of pellets were marked by an almost unchanged feed intake compared with the standard groups. In some experiments, including ours, the chicks fed enzyme supplemented diets consumed even less feed than chicks fed unsupplemented diets. Higher weight gains were linked with improved feed/gain ratios. For these experiments the improved growth of the animals can only be explained by better energy and nutrient metabolizability, since there were hardly any differences in the body composition between "standard" and "enzyme" broilers. In some cases, broilers fed the enzyme-supplemented diets were a little fatter as a result of greater energy supply.

In growth tests combined with measurements of the metabolizability of energy a direct relationship between the performance and the influence of the supplemented enzymes on metabolizable energy of diet may by established. Thus Carré et al. (1992) and Gippert et al. (1994) succeeded to prove in broiler growth tests with wheat or barley diets that an increase in final fattening weight and feed/gain ratio after a 42-day fattening period was also accompanied by higher metabolizability of energy (Table 7). The measurements of the influence of feed enzymes on the content of metabolizable energy in grains or grain-enriched feed mixtures furnished rather discrepant results. The evaluation of experiments with barley and barley-enriched mixtures revealed an energy increase by $1.5-15 \%$ for barley and $0-41 \%$ for barley-enriched mixtures (Table 8 ). This enormous variation may have different causes. An essential factor might be the varying

TABLE 7

Effect of enzyme addition to wheat or barley based broiler rations on performance of birds and on $\mathrm{AME}_{\mathrm{N}}$ values (Carré et al., 1992, Gippert et al., 1994)

\begin{tabular}{|c|c|c|c|c|c|c|}
\hline \multirow[t]{2}{*}{ Enzyme } & \multicolumn{2}{|c|}{ Live body weight* } & \multicolumn{2}{|c|}{ Feed: gain } & \multicolumn{2}{|c|}{$\mathrm{AME}_{\mathrm{N}}$} \\
\hline & $\mathrm{g}$ & $\%$ & $\mathrm{~kg} / \mathrm{kg}$ & $\%$ & $\mathrm{MJ} / \mathrm{kg}$ & $\%$ \\
\hline - & 1624 & 100 & 2.23 & 100 & 11.23 & 100.0 \\
\hline$t^{\prime}$ & 1736 & 107 & 2.09 & 93.5 & 11.96 & 106.5 \\
\hline - & 1576 & 100 & 2.29 & 100 & 12.57 & 100 \\
\hline$t^{2}$ & 1629 & 103 & 2.20 & 96 & 12.83 & 102 \\
\hline
\end{tabular}

' enzyme preparation BioFeed Plus with mainly pentosananase activity

${ }^{2} 100 \mathrm{mg}$ Avizyme/kg

* at $42^{\text {ni }}$ day 
TABLE 8

Influence of B-glucanase preparations on the content of metabolizable energy of barley or barley based diets to broilers

\begin{tabular}{|c|c|c|c|c|}
\hline Reference & Barley type & - Enzyme & + Enzyme & Change $(\%)$ \\
\hline Aboud et al. (1990) & 6 row, hulled' & 13.4 & 13.6 & +1.5 \\
\hline Brufau et al. (1993) & $\begin{array}{l}6 \text { row, hulled } \\
2 \text { row, hulled }\end{array}$ & $\begin{array}{l}12.77 \\
13.69\end{array}$ & $\begin{array}{l}13.36 \\
13.74\end{array}$ & $\begin{array}{r}+5 \\
0\end{array}$ \\
\hline Jeroch et al. (1995a) & 6 row, hulled' & 13.0 & 13.7 & +5 \\
\hline \multirow[t]{2}{*}{ Rotter et al. (1990) } & Hull-less ${ }^{1}$ & 11.1 & 13.9 & +13 \\
\hline & Hulled' & 12.6 & 12.8 & +1.5 \\
\hline Rutkowski (1992) & Hulled' & 13.1 & 12.9 & -1.5 \\
\hline Aboud et al. (1990) & 6 row, hulled' & 11.6 & 11.8 & +1.5 \\
\hline Broz and Frigg (1986) & Hulled $^{2}$ & 12.4 & 12.7 & +2 \\
\hline \multirow[t]{2}{*}{ Friesen et al. (1992) } & Hulled $^{2}$ & 14.8 & 15.8 & +7 \\
\hline & Hull-less ${ }^{2}$ & 11.4 & 16.1 & +41 \\
\hline Francesch et al. (1994) & $\begin{array}{l}2 \text { row, hulled }{ }^{2} \\
2 \text { row, hulled }\end{array}$ & $\begin{array}{l}13.3^{3} \\
13.03^{4}\end{array}$ & $\begin{array}{l}13.48^{3} \\
13.41^{4}\end{array}$ & $\begin{array}{l}+1.5 \\
+3\end{array}$ \\
\hline $\mathrm{McNab}(1993)$ & & 11.54 & 12.04 & +4 \\
\hline $\begin{array}{l}\text { Vukic Vranjes and Wenk } \\
\text { (1995) }\end{array}$ & 2,4 & 14.33 & 14.56 & +1.6 \\
\hline
\end{tabular}

content of soluble NSP in the cereal species or diets and the viscosity ensuing therefrom. In most cases higher viscosity of the hull-less compared to the hulled barley varieties was observed (Rotter et al., 1990; Friesen et al., 1992).

The energy value of wheat-based and wheat-enriched diets also increase after enzyme supplementation (Carré et al., 1992), (Table 9). This substantiated the investigations by Annison $(1991,1992)$ which proved beyond doubt that variations in the content of metabolizable energy of Australian wheat varieties $(11.25-13.59 \mathrm{MJ} / \mathrm{kg} \mathrm{DM})$ are connected with varying concentration of water-soluble NSP. The Australian research team attributed the differences in the content of metabolizable energy for chicks between cereal species principally to the varying concentrations of NSP (pentosans and B-glucan) (Figure 2). The correlation between NSP content in cereals and the metabolizability of energy is 
TABLE 9

Influence of enzyme supplementation to a wheat based diets on the content of metabolizable energy for broiler chicks, $\mathrm{AME}_{\mathrm{N}}, \mathrm{MJ} / \mathrm{kg}$

\begin{tabular}{llccc}
\hline Reference & Diet & - Enzyme & + Enzyme & Change (\%) \\
\hline Annison (1992) & Wheat based & 14.26 & 15.45 & +8 \\
Carré et al. (1992) & Wheat based & 12.54 & 13.35 & +6 \\
Friesen et al. (1992) & Wheat based & 14.13 & 14.71 & +4 \\
McNab (1993) & Wheat & 14.48 & 15.43 & +7 \\
& & 14.4 & 15.26 & +6 \\
Brufau et al. (1992) & Wheat 40\%, maize 15\% & 13.31 & 13.88 & +4 \\
Francesch et al. (1994) & Wheat 40\%, maize 21\% & $14.12^{1}$ & $14.25^{1}$ & +1 \\
& & $13.6^{2}$ & $13.6^{2}$ & 0 \\
\hline
\end{tabular}

${ }^{1}$ coarse meal

${ }^{2}$ pellets

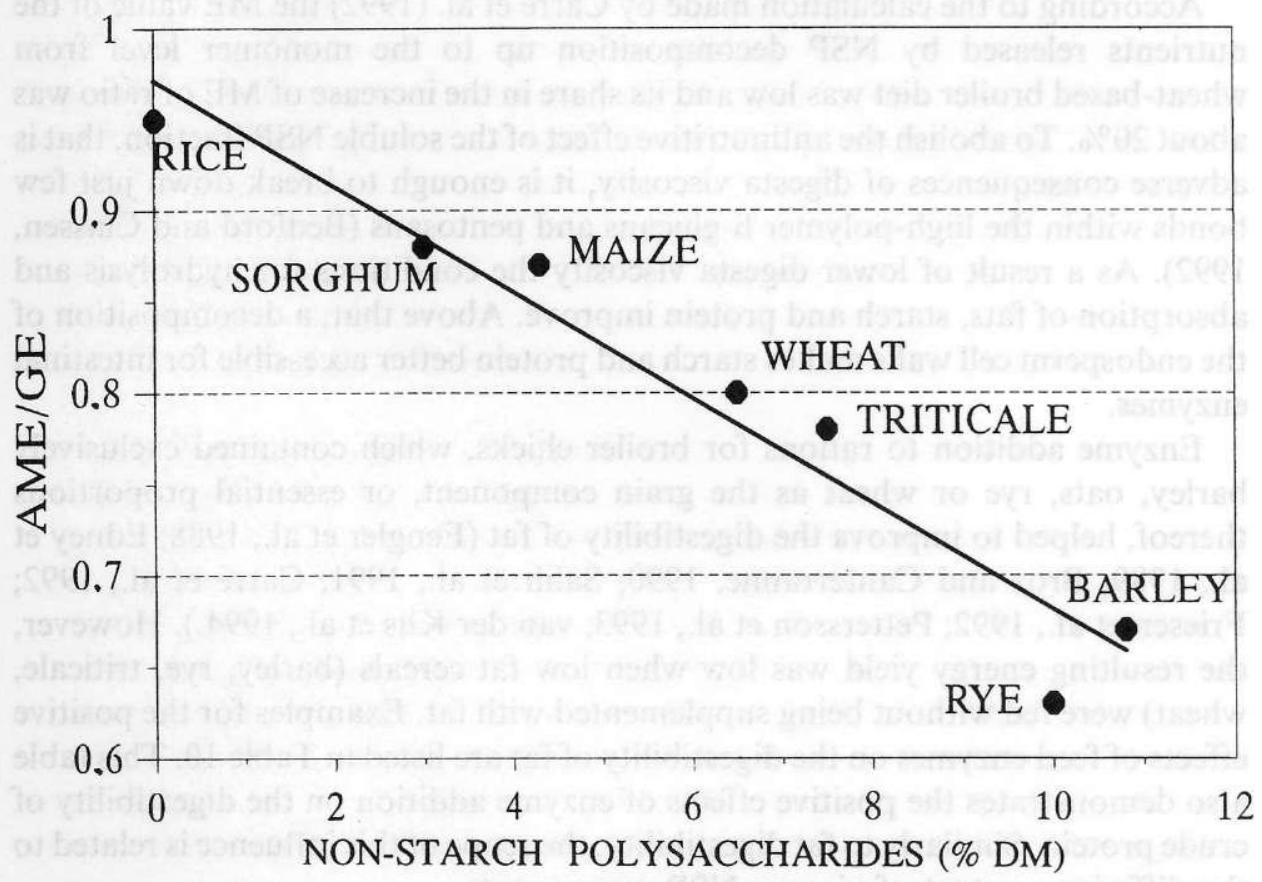

Figure 2. The relationship between energy metabolizability of cereals and their non-starch polysaccharide composition (pentosan + B-glucans, \% dry matter) (Choct and Annison, 1990) 
high indeed, and there is no doubt that pentosans and B-glucan affect decisively the availability of energy. Yet, oats do not fit in this pattern. Despite an approximately equal content of antinutritive NSP like in barley, its ME content is remarkably lower. In oats beside specific NSP with antinutritive effects there are other cell wall components that affect the metabolizability of energy.

\section{Digestibility of feed nutrients}

According to the available literature, different processes are responsible for the improved availability of energy connected with NSP-decomposing enzyme activities:

- NSP hydrolysis to monomers (D-glucose, D-xylose, L-arabinose),

- improved starch digestibility,

- higher fat digestibility,

- improved protein digestibility.

The energy gain results only partially from NSP hydrolysis to resorbable monosaccharides.

According to the calculation made by Carre et al. (1992) the ME value of the nutrients released by NSP decomposition up to the monomer level from wheat-based broiler diet was low and its share in the increase of $\mathrm{ME}$ of ratio was about $20 \%$. To abolish the antinutritive effect of the soluble NSP fraction, that is adverse consequences of digesta viscosity, it is enough to break down just few bonds within the high-polymer B-glucans and pentosans (Bedford and Classen, 1992). As a result of lower digesta viscosity the conditions for hydrolysis and absorption of fats, starch and protein improve. Above that, a decomposition of the endosperm cell walls makes starch and protein better accessible for intestinal enzymes.

Enzyme addition to rations for broiler chicks, which contained exclusively barley, oats, ryc or wheat as the grain component, or essential proportions thereof, helped to improve the digestibility of fat (Fengler et al., 1988; Edney et al., 1989; Broz and Canterranne, 1990; Salih et al., 1991; Carré et al., 1992; Friesen et al., 1992; Pettersson et al., 1993; van der Klis et al., 1994.). However, the resulting energy yield was low when low fat cereals (barley, rye, triticale, wheat) were fed without being supplemented with fat. Examples for the positive effects of fecd enzymes on the digestibility of fat are listed in Table 10. This table also demonstrates the positive effects of enzyme addition on the digestibility of crude protein. Similarly to fat digestibility, the scope of this influence is related to the differing content of viscous NSP components.

Improved crude protein digestibility was reported by Broz (1987), Broz and Canterranne (1990) and Pettersson et al., (1993) for rye-containing diets, by 
TABLE 10

Effect of enzyme preparation on metabolizable energy and nutrient digestibility of barley or barley based diets for broiler chicks

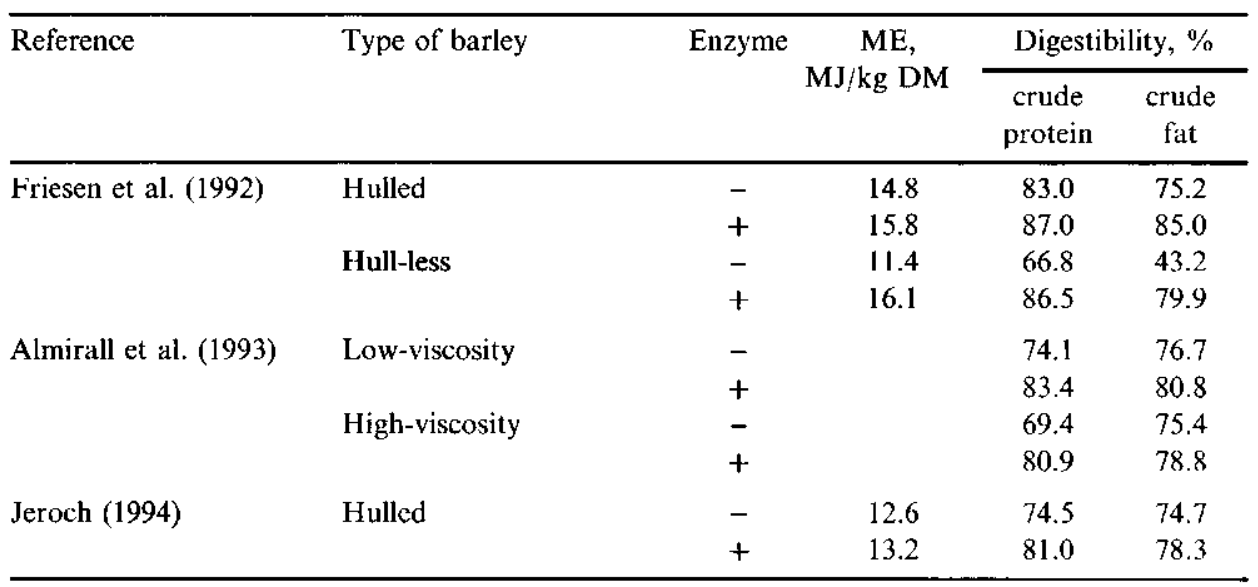

Carré et al. (1992) for a wheat diet and by Rotter et al. (1990) for rations based on barley, oats and rye. In contrast to this, practically no improvement of crude protein digestibility after enzyme addition was found by Aboud et al. (1990) with barley and barley-enriched fced rations.

Enzyme additives helped also to improve the digestibility of cereal starch when grain crops or single varieties with increased NSP concentration were fed. Carré et al. (1992) reported a rise of starch digestibility from 95 to $98 \%$ when broiler chicks were fed wheat-enriched diets. Annison (1992) reported that the ileal digestibility of the starch in wheat rations improved after enzyme addition from 88 to $96-98 \%$. Equally evident was the increase of starch digestibility in a diet containing rye endosperm (Pettersson et al., 1993).

\section{Digesta passage rate and feed intake}

An enzyme-conditioned decrease of the digesta viscosity may entail faster feed passage. Investigations by Salih et al. (1991), Almirall and Esteve-Garcia (1994) and also our own experiments, carried out with barley-based rations with or without enzyme supplementation, demonstrated accelerated passage of the digesta (Figure 3). This enables a higher feed intake as was recorded in numerous experiments. The involved increasc in the energy and nutrient supply might be an essential factor for the intensified growth of broilers fed enzyme-supplemented diets. 


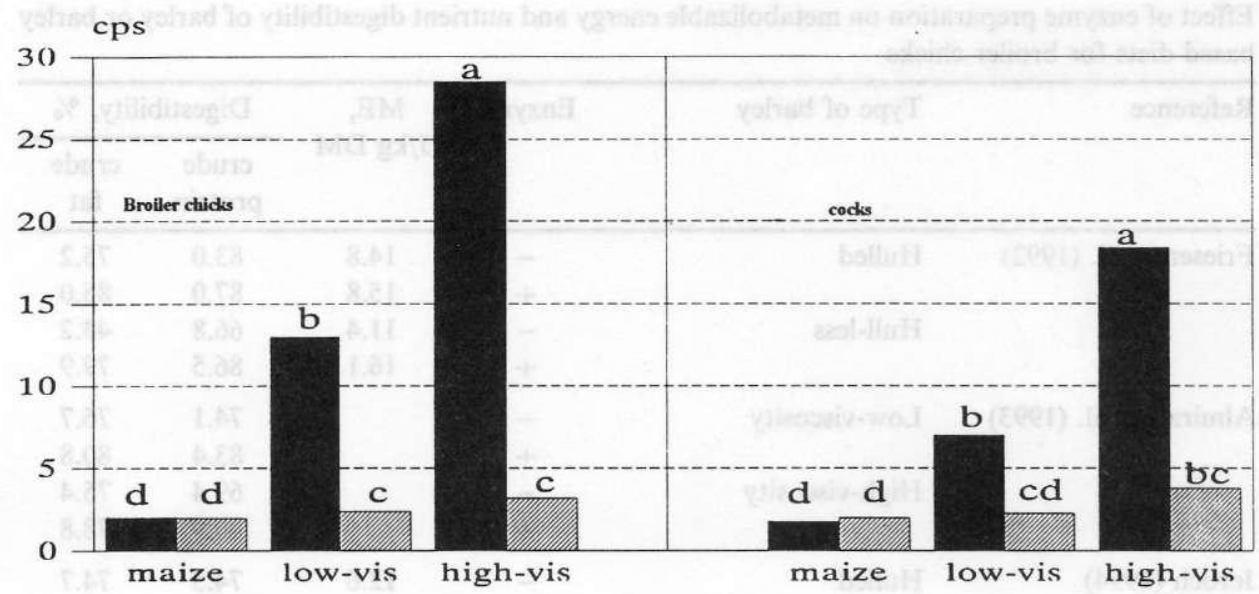

Without B-glucanase With B-glucanase

Figure 3. Passage time of barley based diets fed to broiler chickens (Jeroch et al., 1990)

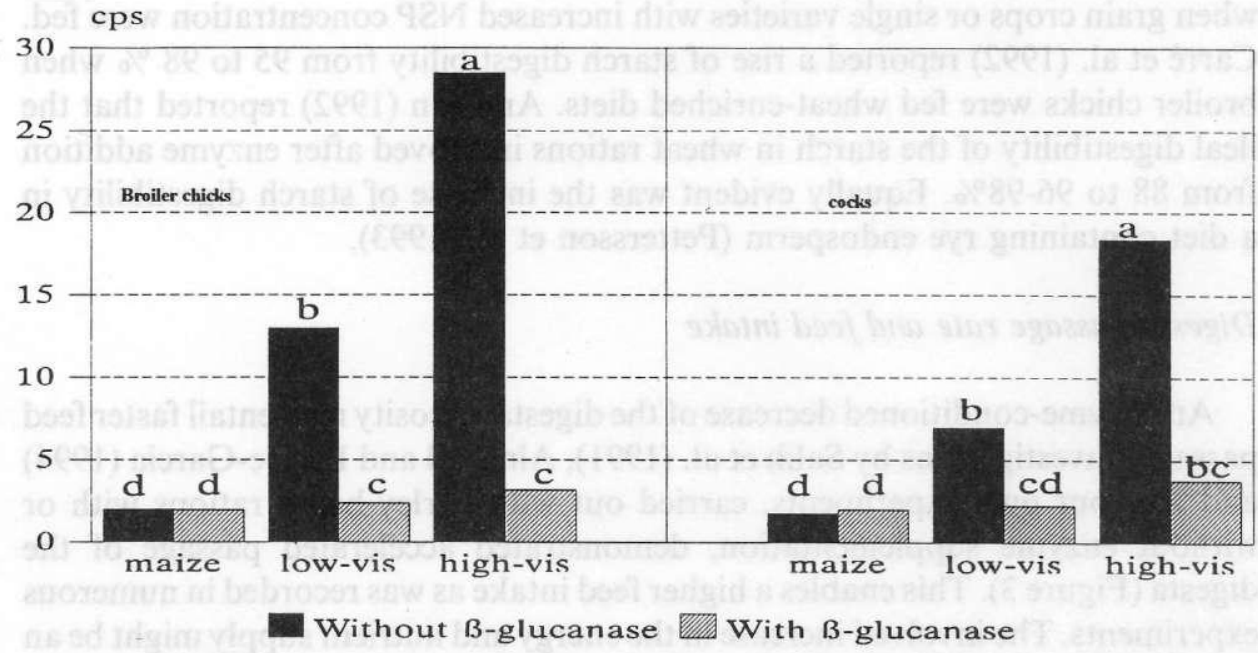

Figure 4. Influence of high or low viscosity barley fed to broilers and cocks, unsupplemented or B-glucanase-supplemented, on the foregut viscosity (Almirall et al., 1993) 


\section{Digesta viscosity}

The repeatedly mentioned rise in digesta viscosity after the application of feedstuffs or feed mixtures containing soluble NSP can be excluded by substrate-specific enzyme preparations. The effect of enzyme containing xylanase and B-glucanase acitivities was particularly impressive in tests by Bedford and Classen (1992) with rations in which wheat was gradually substituted by rye. For barley-enriched diets Aboud et al. (1990), Salih et al. (1991) and Almirall et al. (1993) succeeded in showing the viscosity-lowering effect of added B-glucanase. In addition, Almirall et al. (1993) demonstrated the age-effect on digesta viscosity in barley feeding and its reduction by enzyme supplementation (Figure 4).

\section{Demands for enzyme preparations}

According to Simon et al. (1993), because of the nature of the digestive tract and feed technology, exogenous feed enzyme should fulfill special demands:

1. High thermostability.

This aspect plays an important part in processing poultry feed, especially in process of pelleting as high temperature in process of pelleting decreases the activity of feed enzymes. Protection of enzymes by technical and technological means is a challenge for enzyme producers (Sasserod, 1993).

2. Maintenance of activity in the acidic $\mathrm{pH}$ range and high $\mathrm{pH}$-stability.

There is a wide range of changing $\mathrm{pH}$ values throughout the alimentary tract and enzymes should maintain their activity after passing through the stomach (lowest $\mathrm{pH}$ ) to be effective in the foregut.

3. No toxicological concerns.

As to the discussed specificity of enzymes with regard to their substrates it is recommendable to use enzymes or enzyme cock tails with activity closely fitted to the known substrates of feed or diet. Only in this way it becomes possible to overcome the heterogeneous experimental results discussed above.

\section{Benefits of exogenously supplemented enzymes}

Chicks that are fed barley, oat or rye rations void watery and sticky excreta. The altered faeces stick to the anus, pollute plumage, feeding and drinking facilities, deteriorate litter and housing climate. These grave disadvantages are much more expressed in practice than in the laboratory experiments. Enzyme addition to rations containing risky cereals may help to reduce or avoid the described problems. Even when high rye proportions (30\%) were incorporated in the broiler diet, excreta consistency after enzyme addition corresponded to that 
of maize-fed animals (Jackisch and Jeroch, 1990). The stickiness of faeces on barley rations can also be drastically reduced by enzyme supplementation (Brufau et al., 1991, Elwinger and Teglöf, 1991). Therefore, it is important to assess the effectiveness of enzyme preparations not only on the basis of growth improvement and the decrease of the feed/gain ratio. Enzyme addition induced also a decline in the number of dirty chicks as well as lower water consumption (Brufau et al., 1991; Jeroch et al., 1995a). Thus, enzyme supplementation may lead to better sanitary and environmental conditions and to reduction of production risk.

\section{CONCLUSIONS}

Exogenous enzyme supply may improve quality and feeding effect of feed mixtures containing cereals with antinutritively acting NSP. As shown in comparative trials, the same fattening results are possible as with mixtures based on maize. Feed producers and farmers may incorporate greater proportions of risky cereals in poultry rations when feed enzymes are added.

Table 11 gives recommendations for the input of such cereals with and without enzyme addition. The results obtained with enzyme-supplemented wheat rations have again raised the question about the NSP threshold in the feed beyond which antinutritive effects must be expected. The dosage of enzymes is important mainly from the economical point of view, and should be related to the proportion of soluble NSP in feed mixture. The doses applied in the majority of experiments represent only orientation aids for practical conditions, because feed

TABLE 11

Limits for cereal percentages in mixed feeds for gallinaceous birds

\begin{tabular}{|c|c|c|c|c|c|c|c|c|c|c|}
\hline \multirow{2}{*}{$\begin{array}{l}\text { Strain } \\
\text { Enzyme }\end{array}$} & \multicolumn{2}{|c|}{ Barley } & \multicolumn{2}{|c|}{ Oats } & \multicolumn{2}{|c|}{ Rye } & \multicolumn{2}{|c|}{ Triticale } & \multicolumn{2}{|c|}{ Wheat } \\
\hline & $--^{2}$ & + & $-^{2}$ & + & $-^{2}$ & + & -1.2 & + & $-1,2$ & + \\
\hline Chicks & 10 & 40 & $10-30^{3}$ & n. $1 .^{3}$ & 5 & 20 & 20 & n.1. & 30 & n.l. \\
\hline Pullets & 30 & n.1. & $20-30$ & n.1. & 15 & 30 & 30 & n.1. & 40 & n.1. \\
\hline l.ayers & 60 & n. $1^{4}$ & 20 & 40 & 20 & 40 & 30 & n.1. & 40 & n.1. \\
\hline $\begin{array}{l}\text { Broiler } \\
\text { chickens }\end{array}$ & 10 & 40 & $10-30^{3}$ & n..$^{3}$ & 5 & 20 & 20 & 40 & 20 & n.l. \\
\hline
\end{tabular}

n.1. = no limit

varieties with lower energy and higher pentosan content

${ }^{2}$ recommendations only for diets without any feedstuffs containing critical specific NSP

${ }^{3}$ husked

${ }^{4}$ improved egg quality and litter condition after enzyme addition 
mixtures in practice are normally based on more components than in most experiments. In view of the remarkably varying NSP content in single cereal crops (for example the B-glucan in barley, pentosan in wheat) an uncomplicated approach to the assessment of the antinutritive potential of NSP would be desirable. A suitable criterion might be the extract viscosity which correlates closely with the soluble NSP content. Unfortunately, the experiments run so far do not allow drawing generally acceptable conclusions because, among other reasons, the data of the available measuring principles are not comparable. The investigations hitherto performed demonstrated that enzyme preparations are able to hydrolize NSP only to a minor extent to resorbable monomers. In contrast to the avoidance of antinutritive effects, the challenge to fermentative decomposition is much greater here.

\section{REFERENCES}

Aboud M., Müller A., Jeroch 11., 1990. Ernährungsphysiologische Bewertung von Enzymzusätzen beim Geflügel. Procecdings of Internationale Tagung Schweine- und Geflügelernährung, Leipzig, pp. 121-125

Aimonen E. M. J., Näsi M., 1991. Replacement of barley by oats and enzyme supplementation in diets for laying hens. Acta Agric. Scand. 41, 179-192

Alexander H. P., Fish J., 1984. Total B-glucan content of 23 barley varieties from the 1983 harvest. J. Inst. Brew, 90, 65-66

Almirall M., Brufau J., Esteve-Garcia E., 1993. Effects of internal viscosity on digestive enzyme activitics of intestinal content and ileal digestibilies of poultry fed barley diets at different ages supplemented with B-glucanases. Proceedings of Symposium on Enzymes in Animat Nutrition, Zurich, pp. 69-72

Almirall M., Esteve-Garcia E., 1994. Rate of passage of barlcy diets with chromium oxide,influence of age and poultry strain and effect of B-glucanase suppiementation. Poultry Sci. 73, 1433-1440

Åman P., Graham A., 1987. Analysis of total and insoluble mixed-linked $(1 \rightarrow 3)(1 \rightarrow 4)$-B-D-glucans in barley and malt. J. Agric. Food Chem. 35, 704-709

Annison G., 1990. Polysaccharide composition of Australian wheats and the digestibility of their starches in broiler chicken diets. Aust. J. Exp. Agric. 30, 183-186

Annison G., 1991. Relationship between the levels of soluble nonstarch polysaccharides and the apparent metabolizable energy of wheats assayed in broiler chickens. J. Agric. Food Chem. 39, $1252-1256$

Annison G., 1992. Commercial enzyme supplementation of wheat-based diets raises ileal glycanase activities and improves AME, starch and pentosan digestibility in broiler chickens. Anim. Feed Sci. Technol. 38, 105-121

Batterham E. S., Saini H. S., Andersen L.M., 1988. Nutritional value and carbohydrate content of ryc and wheat for growing pigs. Nutr. Rep. Intern. 38, 809-818 
Bedford M. R., 1992. The effect of dictary enzymes on digestion in poultry. Feed Compounder, November

Bedford M. R., Classen H.L., 1992. Reduction of intestinal viscosity through manipulation of dietary rye and pentosanase concentration is affected through changes in carbohydrate composition of the intestinal aqueous phase and results in improved growth rate and fecd conversion efficiency of broiler diets. J. Nutr. 122, 560-569

Benabdeljelil K., 1991. Effects of enzyme supplementation of barley based diets on hen performance and egg quality. Proceedings of 8th Europcan Symposium on Poultry Nutrition, Veneria-Mestre, (Italy), pp. 337-342

Broz J., 1987. Improvement of the nutritive value of rye for broiler chickens by supplemental enzymes. Proccedings of 6 European Symposium on Poultry Nutrition, Königslutter (Germany), P6-P7

Broz J., 1991. Effects of Roxazyme G on the nutritive value of various broiler diets. Proceedings of Roche Symposium on Animal Nutrition and Health, Basel/Village-Nouf, p. 131

Broz J., Canterranne E., 1990. Effect of enzyme supplementation on the nutritive value of rye-based dicts for broiler chickens. Procecdings of Intcrnationale Tagung Schwcinc- und Geflügelernährung, Leipzig, pp. 231-234

Broz J., Frigg M., 1986. Effects of cellulolytic enzyme products on the feeding value of various broiler dicts. Arch. Geflügelk. 50, 104-110

Brufau J., Nogareda C., Perez-Vendrell A., Francesch M., Esteve-Garcia E., 1991. Effects of Trichoderma viride enzymes in pelleted broiler diets based on barley. Anim. Feed Sci. Technol. $34,193-202$

Brufau J., Francesch M., Legarda J. E., Perez-Vendrell A. M., Esteve-Garcia E., 1992. The effect of an enzyme supplement on the apparent metabolizable energy of a wheat in broiler diets. Proceedings of 19 World's Poultry Congress, Amsterdam, Vol. 3, p. 452

Brufau J., Perez-Vendrell A., Francesch F., 1993a. Ffficiency of enzyme preparations in monogastrics regarding the reproducibility and the methodology used. Report EC Workshop on Microorganisms and Enzyme Preparations in Animal Nutrition, pp. 13-22

Brufau J., Francesch M., Percz-Vendrell A.M., Estcve-Garcia E., 1993b. Effects of postharvest storage on nutritive value of barley in broilers. Proceedings of the I Symposium on Enzymes in Animal Nutrition, Kartause Ittingen (Switzerland), pp. 125-128

Brufau J., Cos R., Perez-Vendrell A.M., Esteve-Garcia E., 1994. Performance of laying hens as affected by the supplementation of a barley-based dict with a crudc enzyme preparation from Trichoderma viride. Can. J. Anim. Sci., 74, 129-134

Carré B., Lessire M., Nguyen T.H., Larbier M., 1992. Effect of enzyme on feed efficiency and digestibility of nutrients in broilers. Proceedings of 19 World's Poultry Congress, Amsterdam, Vol. 3, 411-415

Choct M., Annison G., 1990. Antinutritive activity of wheat pentosans in broiler diets. Brit. Poultry Sci. $31,811-822$

Edney M.J., Campbell G.L., Classen H.L., 1989. The cffect of B-glucanase supplementation on nutrient digestibility and growth in broilers given diets containing barley, oat groats or wheat. Anim. Feed Sci. Technol. 25, 193-200

Elwinger K.. Teglöff B., 1991. Performance of broilcr chickens as influencend by a dietary enzyme complex with and without antibiotic supplementation. Arch. Geflügelk. 55, 69-73

Escribano F., Rahn B.E., Sell J.L., 1988. Develpoment patterns of selected characteristics of the gastrointestinal tract of young turkeys. Poultry Sci. 67, 1089-1097

Fengler A.I., Pawlik J.R., Marquardt R.R., 1988. Improvement in nutrient retention and changes in cxcreta viscosities in chicks fed rye-containing diets supplemented with fungal enzymes, sodium taurocholate and penicillin. Can. J. Anim. Sci. 68, 483-491 
Francesch M., 1991., Valoracion nutritiva de cebadas para la alimentacion aviar. Ph. D. Thesis, Univ. Autonoma, Barcelona

Francesch M, Perez-Vendrell A., Brufau J., 1989. Valoracion nutritiva de cebadas en alimentacion de broilers. Mejora de su utilizacion. Proceedings of 18 Symposium de la Scccion Espanola de la WPS $\Lambda$, Expoaviga, Barcelona, p. 135

Francesch M., Percz-Vendrell A., Esteve-Garcia E., Brufau J., 1994. Effects of cultivar, pelleting and enzyme addition on nutritive value of barley in poultry diets. Brit. Poultry Sci. 35, 259-272

Francesch M., Perez-Vendrell A., Molina-Cano J.L.. Brufau J., 1992. Effects of variety, location and year of harvest on the nutritive value in poultry of Spanish barleys. Proceedings of Conference on Barlcy for Food and Mait, Uppsala (Sweden)

Friesen O.D., Guenter W., Marquardt R.R., Rotter B.A., 1992. The effect of enzyme suppiementation on the apparent metabolizable energy and nutrient digestibilities of wheat, barley, and rye for the young broiler chicks. Poultry Sci. 71, 1710-1721

Gippert T., Dolmany T., Halmagyi T., Gerendai D., Dinnyes J., 1994, Effect of enzymes on the digestibility of broiler feeds with barley content and on the performance of chickens. Proceedings of 9 European Poultry Conference, Glasgow, Vol. I, pp. 427-428

Gruzauskas R., Jeroch H., Jeroch K., Sirvydis V., Danius S., Bobina A., 1991. Effect of different enzyme preparartions on the performance of laying hens fed with feed mixture based on barley. Proceedings of International Conference "Industrial Enzymes, Probiotics and Biological Additives", Kaunas, pp. 32-35

Gruzauskas R., Jeroch H., 1992. Nichtstärkepolysaccharide und Futterwert von Gerste für das Geflügel. Proceedings of Internationale Tagung Schweine- und Geflügelernährung, IIalle/Saale, pp. 129-136

Hamilton R. N.G., 1994. Effects of level of naked oats (Avena nuda) and B-glucanase supplementation of starter diets on the performance of turkey broilers. Proceedings of 9 European Poultry Conference. Glasgow, Vol. I, pp. 429-430

Henry R. J., 1987. Pentosan and $(1 \rightarrow 3)(1 \rightarrow 4)$-B-gluean concentrations in endosperm and whole grain of wheat, bariey, oats and rye. Cereal Sci. 6, 253-258

Herstad O., 1987. Cereal with higher fiber content (barley, oats, millet). Proceedings of 6 European Symposium on Poultry Nutrition, Königslutter (Germany). A15-A23

Hesselman K., 1989. The use of enzymes in poultry diets. Proceedings of 7 European Symposium on Poultry Nutrition, Lloret de Mar, Girone (Spain), pp. 31-48

Jackisch B., Jeroch H., 1990. Untersuchungen zur Verbesserung des Futterwertes von roggenreichem Broilermastfutter durch Enzymzusatz. Arch. Anim. Nutr. 40, 1109-1118

Jackisch B., Jeroch H., 1992. Ergebnisse weiterer Prüfungen von roggenhaltigen Futtermischungen mit dem Enzympräparat "Nutrizym-feed-additive" in der Broilermast. Arch. Anim. Nutr. 42, $55-61$

Jeroch H., Müller A., Gebhardt G., 1990. Einfluß einer Beta-Glucanase supplementation auf die Verdaulichkeit verschiedener Gerstensorten beim Broilerküken. Proceedings of 8 European Poultry Conference, Barcelona, pp. 259-262

Jeroch H. 1991. Gerste als Futtermittel für Legehennen. Arch. Tierzucht 34, 581-590

Jeroch H., Helander E., Schlöffel H.J., Engerer K.H., Pingel H., Gebhardt G., 1991. Prüfung der Wirksamkeit des Beta-Glucanase enthaltenden Enzympräparates "Avizyme" zu einer Broiler-mischung auf Gerstebasis. Arch. Geflügelk. 55, 22-25

Jeroch H., Engerer K.H., 1992. Effect of a B-glucanase containing multienzyme preparation to geese fattening mixtures on barley basis. Proceedings of 9 International Symposium on Watcrfowl, Pisa (Italy), pp. 159-161

Jeroch H., Müller A., 1992. Futterenzyme in der Geflügelernährung. Lohmann Information, pp. 5-11 
Jeroch H., Gruzauskas R., Siebecke-Strempel H., Völker L., 1995a. The effect of variety on the nutritive value of barley for broiler chickens and the efficiency of enzyme preparation. Submitted for publication

Jeroch H., Schurz M., Gruzauskas R., Siebecke-Strempel H., Völker L., 1993. The efficiency of enzyme additives to broiler rations on wheat basis. Proceedings of the 1 Symposium on Enzymes in Animal Nutrition, Kartause Ittingen (Switzerland), pp. 144-147

Jeroch H., Schurz M., Völker L., 1995. The influence of enzyme additions to a barley-based ration on the fattening performance of Muscovy ducks. Arch. Geflügclk. 59, 223-227

Krogdah1 A., Sell J.L., 1989. Influence of age on lipase, amylase and protease activites in pancreatic tissue and intestinal contents of young turkeys. Poultry Sci. 68, 1561-1568

McNab J. M., 1993. Optimal use of enzymes for special ingredients. Proceedings of the 1 Symposium on Enzymes in Animal Nutrition, Kartause Ittingen (Switzerland), pp. 97-124

McNab J.M., Whitehead C.C., Voelker L., 1993. The effects of dietary enzyme addition on broiler performance and on the $\mathrm{AME}_{\mathrm{N}}$ values of these diets and wheat. Proceedings of 9 European Symposium on Poultry Nutrition., Jelenia Góra (Poland), pp. 479-484

Näsi M., 1988. Enzyme supplementation of laying hen diets based on barley and oats. Proceedings of Alltech 4 Animal Symposium, Nlltech Technical Publications, pp. 199-204

Pcrez-Vendrcll A. M., Francesch M., 1991. Analytical methods to cvaluate barley quality for monogastric nutrition. Proceedings of Seminar "New Trends in Barley Quality for Malting and Feeding", Barcelona, pp. 75-85

Pettersson D., Åman P., 1988. Effects of enzyme supplementation of diets based on wheat, rye or triticale on their productive value for broiler chickens. Animal Feed Sci. Technol. 20, 313-324

Pettersson D., Frigard T., Åman P., 1993. The use of enzymes to improve the nutritive value of feed. Proceeding 9 European Symposium on Poultry Nutrition, Jelenia Góra (Poland), pp. 232-242

Richter G., Ranft U., Petzold A., Schwartze J., 1990. Einfluß von Enzympräparaten auf die Leistungen von Broilern bei Einsatz von Roggen. Arch. Anim. Nutr. 40, 951-958

Richter G., 1994., cit. by Müller A. Novo Nordisk Symposium "Aktueller Stand des Einsatzes von Enzymen in der Fütterung", 7 October 1994, Kopenhagen

Rotter, B.A., Friesen O.D., Guenter W., Marquardt R.R., 1990. Influence of enzyme on the bioavailable energy of barley. Poultry Sci. 69, 1174-1181

Rutkowski A., 1992. Einfluß von Enzymzusätzen auf die Umsetzbarkeit der Energie und AS-Resorption. Proceedings of Internationale Tagung Schweine- und Geflügelernährung. Halle/Saale, pp. 114-119

Saastamoinen M., Plaami S., Kumpulainen J., Rantanen O., 1991. Concentrations of water soluble and insoluble $B$-glucan and phytic acid in 6-row and 2-row barley varieties. Cereal Res. Com. 19, 391-397

Salih M.E., Classen H.L., Campbell G.L., 1991. Response of chickens fed on hull-less barley to dietary B-glucanasc at different ages. Anim. Fecd Sci. Technol. 33, 139-149

Sasserod S., 1993. Industrielle Enzyme zum Einsatz im Mischfutter. In: Aktuelle Themen der Tierernärung und der Veredlungswirtschaft. Zus. der Vorträge der wiss. Tagung, 20.-21.10.1993, Cuxhaven, Herausgeber: Lohmann-LTE GmbH, Cuxhaven, pp. 19-29

Schutte J. B., Geerse C., Jong de J., 1993. Effect of enzyme supplementation to wheat-based diets on broiler chick performance. Proceedings of the 1 Symposium on Enzymes in Animal Nutrition, Kartause Itingen (Switzerland), pp. 133-136

Scholtyssek S., Knorr R.. 1987. Die Wirkung eines cellulolytischen Enzympräparates bei Verfütterung von Triticale- und Roggenrationen an Broiler. Arch. Geflügelk. 51, 10-15

Seskeviciene J., Gruzauskas R., Dänicke S., Ebert K., Jeroch H., 1994. Inhaltsstoffe und Futterwert litauischer Weizensorten. Proceedings of 3 Tagung Schweine- und Geflügelernährung, Halle/Saalc, pp. 319-322 
Simon O., Politz O., Borris R., 1993. Improving the characteristics of bacterial B-glucanases by construction of hybrid enzymes. Proceedings of the 1 Symposium on Enzymes in Animal Nutrition, Kartause Ittingen (Switzerland), pp. 22-28

Stock H.G., Jeroch H., 1995. Anbauchancen für zweizeilige Wintergerste bei Berücksichtigung von Ertrag und Inhaltsstoffen. Bodenkultur 46 (in press)

Van der Klis J.D., Versteegh II.A.J., Scheele C.W., 1994. Practical enzyme use in broiler diets. Phytase and NSP enzymes. BAFS-Symposium, USA, pp. 1-14

Veldman A., Vahl H.A., 1993. Xylanase in whcat-based broiler diets. Proceedings of the 1 Symposium on Enzymes in Animal Nutrition, Kartause Ittingen (Switzerland), pp. 137-140

Völker L., Tüller R., 1993. Effect of Roxazyme G supplementation to wheat and wheat/barley based diets on the performance of growing turkeys. Proceedings of the 1 Symposium on Enzymes in Animal Nutrition, Kartause Ittingen (Switzerland), pp. 141-143

Vukic Vranjes M., Wenk C., 1993. Influence of dietary enzyme complex on broiler performance in diets with and without antibiotic supplementation. Proceedings of the 1 Symposium on Enzymes in Animal Nutrition, Kartause Ittingen (Switzerland), pp. 152-155

Vranjes M., Wenk C., 1995. Influence of dietary enzyme complex on the broiler performance fed on diets with and without antibiotic supplementation. Brit. Poultry Sci. 36, 265-276

Vukic Vranjes M., Pfirter H.P., Wenk C., 1994. Influence of processing treatment and type of cereal on the effect of dietary enzymes in broiler diets. Anim. Feed Sci. Technol. 33, 139-149

Wenk C., 1993. What are the benefits of carbohydrases in the nutrition of mongastric farm animals. Procecdings of the 1 Symposium on Enzymes in Animal Nutrition, Kartause Ittingen (Switzerland), pp. 41-48

\section{STRESZCZENIE}

Wplyw preparatów enzymatycznych na wartość odżywczą zbóz dla drobiu

Dodatck preparatów enzymatycznych do mieszanck zbożowych dla drobiu możc znacznie poprawić wyniki produkcyjne oraz obniżać lepkość treści przewodu pokarmowego. Jednak końcowy efekt zależy w dużym stopniu od zawartości w mieszance niektórych polisacharydów niesk robiowych (NSP) oraz od wieku ptaków. W pracy podano średnią zawartość NSP wykazujących dzialanie antyżywieniowe $\mathrm{w}$ jęczmieniu, pszenicy, pszenżycie i życie oraz przedyskutowano ich wpływ na procesy zachodzące $w$ przewodzie pokarmowym ptaków w różnym wieku, jak również wpływ enzymów egzogennych dodawanych do mieszanek na te procesy. 